\title{
An umbilical bleeding nodule
}

\author{
Hemal Shah, ${ }^{1}$ Salvador Diaz-Cano, ${ }^{2}$ Lucia Pozo-Garcia'
}

'Department of Dermatology, Lewisham and Greenwich NHS Trust, London, Greater London, UK

${ }^{2}$ Department of Histopathology, King's College Hospital NHS Foundation Trust, London, London, UK

\section{Correspondence to}

Dr Lucia Pozo-Garcia, Ipozo@doctors.org.uk

Accepted 2 June 2017

\section{DESCRIPTION}

A 23-year-old woman was referred to the dermatology department through the 2 -week wait pathway under clinical suspicion of malignant melanoma in the umbilical region. She presented with a 4-month history of a painful and intermittently bleeding nodule on the umbilical area. The lesion was more prominent during her menstrual cycles and bled. She was otherwise in good general health and denied a history of abdominal or gynaecological surgery. There was no known medical history of endometriosis.

On physical examination, she presented with approximately $1.5 \mathrm{~cm}$ soft, brown, well-circumscribed nodule on the inferior aspect of the umbilical area (figure 1). Based on her medical history and examination findings, umbilical endometriosis was suspected. A cutaneous biopsy was performed, which showed endometrial glands and stroma without atypia and scattered siderophages (figure 2). The patient was referred to the gynaecology team for further investigation. Ultrasound studies and abdominal/pelvic tomography did not show any evidence of concomitant pelvic endometriosis. She underwent local excision of the skin nodule with preservation of the umbilicus. No recurrences have been noticed after 1-year follow-up.

Endometriosis is defined by the presence of functional endometrial tissue abnormally implanted outside the uterine cavity. Secondary cutaneous endometriosis may occur in surgical scars following hysterectomy, caesarean section, laparoscopy and episiotomy. However, primary (spontaneous) umbilical endometriosis is a rare entity defined by the presence of ectopic endometrial glands and stroma within the umbilicus without any history of pelvic endometriosis or surgery. ${ }^{1}$ It was initially described by Villar in 1886

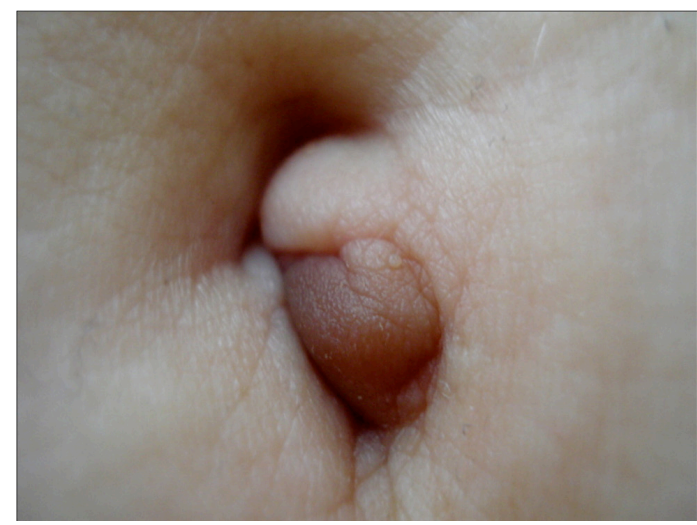

Figure 1 Brown pigmented nodule on the inferior aspect of umbilical area.

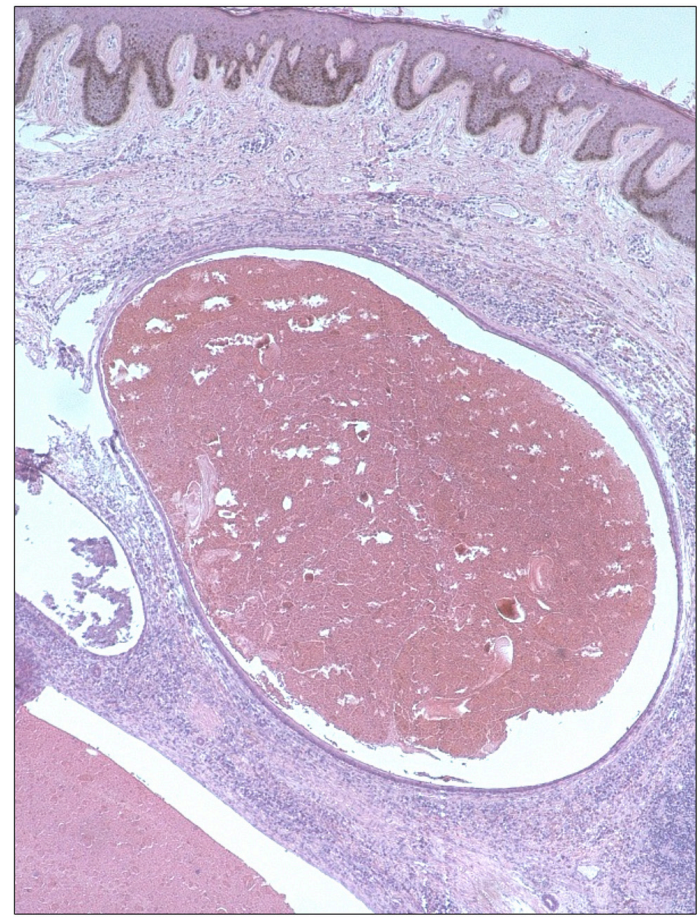

Figure 2 Skin nodule revealed hyperpigmented basal keratinocytes and dilated endometrial-type glands and loose stroma (H\&E 40x).

and is also known as Villar's nodule. It represents $0.5 \%-1 \%$ of all cases of extragenital endometriosis. ${ }^{1}$

The pathogenesis of cutaneous endometriosis is controversial. It may occur following iatrogenic haematological or lymphatic spreading of endometrial cells after abdominal or pelvic surgery in patients suffering from pelvic endometriosis. The aetiology of isolated umbilical endometriosis is not completely understood; metaplasia of urachus remnants has been proposed as a pathogenic mechanism. $^{12}$

It is important to remember that not all bleeding cutaneous lesions are malignant. The differential diagnosis of umbilical nodules is wide, mainly including haemangioma, umbilical hernia and urachus anomalies; less frequently, malignant diseases such as Sister Mary Joseph's nodule, melanoma, sarcoma, adenocarcinoma and lymphoma should be considered. ${ }^{2}$

The risk of malignant transformation from umbilical endometriosis is low. Wide surgical excision is the treatment of choice, but medical hormonal therapy has also been successfully used to relieve the symptoms and to reduce the size of the endometrial nodule. ${ }^{3}$ Primary umbilical endometriosis should always be considered in the differential diagnoses of pigmented nodules on the umbilical region, especially if there is a history of cyclical bleeding, swelling and tenderness during menses. 


\section{Learning points}

- Primary cutaneous endometriosis is the presence of ectopic endometrial tissue in the umbilical area without history of surgery.

- Cutaneous endometriosis should be suspected in case of swelling, tenderness and discharge of any umbilical mass concomitant with the menstrual cycles. A detailed clinical history is crucial for an accurate diagnosis.

- A complete excision and histological confirmation is the treatment of choice.

Contributors HS, SDC and LPG all made substantial contributions in conception, analysis and interpretation of the case report. HS drafted the article, and SDC and
LPG revised it critically for important intellectual content and gave final approval of the submitted version.

Competing interests None declared.

Patient consent Obtained.

Provenance and peer review Not commissioned; externally peer reviewed.

(C) BMJ Publishing Group Ltd (unless otherwise stated in the text of the article) 2017. All rights reserved. No commercial use is permitted unless otherwise expressly granted.

\section{REFERENCES}

1 Pramanik SR, Mondal S, Paul S, et al. Primary umbilical endometriosis: A rarity. J Hum Reprod Sci 2014;7:269.

2 Theunissen Cl, IJpma FF. Primary umbilical endometriosis: a cause of a painful umbilical nodule. J Surg Case Rep 2015;2015:rjv025.

3 Fancellu A, Pinna A, Manca A, et al. Primary umbilical endometriosis. Case report and discussion on management options. Int J Surg Case Rep 2013:4:1145-8.

Copyright 2017 BMJ Publishing Group. All rights reserved. For permission to reuse any of this content visit

http://group.bmj.com/group/rights-licensing/permissions.

BMJ Case Report Fellows may re-use this article for personal use and teaching without any further permission.

Become a Fellow of BMJ Case Reports today and you can:

- Submit as many cases as you like

- Enjoy fast sympathetic peer review and rapid publication of accepted articles

- Access all the published articles

Re-use any of the published material for personal use and teaching without further permission

For information on Institutional Fellowships contact consortiasales@bmjgroup.com

Visit casereports.bmj.com for more articles like this and to become a Fellow 